ESJ Social Sciences

\title{
The Influence of Electronic Personalization on Performance of Three to Five-Star Hotels in Kenya
}

\author{
Sylvia Mukenyi Gioko \\ Department of Business Administration, \\ Jomo Kenyatta University of Agriculture and Technology, Nairobi, Kenya \\ Elegwa Mukulu \\ College of Human Resource Development, \\ Jomo Kenyatta University of Agriculture and Technology, Nairobi, Kenya \\ Margaret Oloko \\ Department of Business Administration, \\ Jomo Kenyatta University of Agriculture and Technology, Nairobi, Kenya
}

Doi:10.19044/esj.2021.v17n23p367

Submitted: 06 April 2021

Accepted: 29 May 2021

Published: 31 July 2021
Copyright 2021 Author(s)

Under Creative Commons BY-NC-ND

4.0 OPEN ACCESS

Cite As:

Gioko S.M., Mukulu E. \& Oloko M. (2021). The Influence of Electronic Personalization on Performance of Three to Five-Star Hotels in Kenya. European Scientific Journal, ESJ, 17(23), 367. https://doi.org/10.19044/esj.2021.v17n23p367

Abstract

Electronic Personalization plays a vital role in the growth and development of the hotel industry, whether in a developed or a developing economy. The hotel industry in Kenya has grown enormously since the year 2000, and despite this growth, the hotel industry in Kenya has experienced slow growth compared to other countries. Electronic Personalization has been identified as an electronic customer relationship management strategy that has had a significant impact on hotel performance. The aim of this study is therefore to seek the influence of Electronic Personalization on the performance of Three to Five-Star Hotels in Kenya. The study adopted a descriptive design for the research. In addition, a quantitative and qualitative research approach was utilized. The target population for the study was one hundred and twelve Three to Five-Star Hotels in Kenya. The study examined one hundred and twelve Three to Five-Star Hotels because they represent the major market share of Kenya's hotel industry. A survey was conducted on the target population. Simple Regression was utilized to draw inference from the data collected. Descriptive findings revealed a mean of 4.524 with a standard 
deviation of 0.5654 for electronic personalization. In addition, findings revealed an R square value of 0.366 between Electronic Personalization and performance. This suggests that Electronic Personalization influences the performance of Three to Five-Star Hotels. Consequently, hotel managers should develop and implement effective Electronic Personalization strategies in their hotel's operations. For instance, they can electronically personalize their hotel information by assigning the right marketing effort to the right customer, hence increasing customer buying behaviour which shall in turn increase performance.

Keywords: Electronic Customer Relationship Management, Electronic Personalization, Performance

\section{Introduction}

Electronic Personalization is commonly used to increase customer's satisfaction, loyalty, trust and trade revenue for companies by making buyer connections almost customized to a single person. With electronic personalization, the company must know customer's needs and preferences, what customers purchase, what product or services they are interested in. The initial step in Electronic Personalization is to gather information of the customer first visit or purchase, then analyze their behavior from the gathered information. This assists a company in being in a position to suggest product or services which customers are interested in. Also, it increases both consumer's loyalty or satisfaction and benefits in terms of profits. Electronic Personalization helps in predicting the customers' needs which therefore improves client's usability of the online pages that adapts the information and services provided by website to single user or set of users (Siddiqui \& Tyagi, 2013).

Electronic Personalization uses the history of a customer's buying behavior and generates a different product list for each user. Electronic Personalization is a part of the electronic customer relationship marketing strategy that involves identifying customers, recognizing their needs so as to establish influences with them. This is accomplished by implementing and proposing services and products in accordance with the characteristics of customers or segments. Effective Electronic Personalization begins by collecting customer information through Data Mining during interaction with the customer or user in order to provide customized services. Electronic Personalization provides features such as personalized product recommendations, because companies can keep in touch with their customers through multiple channels, such as e-mail, websites, call centers. With this concept, there is the long-term identification of customers, the storage of 
purchase lists, and the possibility of tracking and logging the navigation actions of each customer (Lee, 2010).

\section{Problem Statement}

The Kenyan Tourism and hotel sector has recorded dismal performance compared to other sectors. Statistics from the Kenya National Bureau of Statistics showed that the sector performed dismally compared to other sectors with a growth rate of 3.9 percent, from the year 2019 to 2020 . The construction sector grew by 6.4 percent, transport and storage sector grew by 12.1 percent (Kenya National Bureau of Statistics, 2020). The main argument goes that the use of e-CRM has a positive impact on business performance, in terms of their profits through increased customer satisfaction and retention (Shahram \& Farhad, 2013; Ishmael, 2015; Macharia \& Thuo, 2011; Mang'unyi, Khabala \& Govender, 2017).

Empirical studies have shown mixed factors that influence performance of hotels in Kenya. In their study of leadership practices and performance of Five-Star Hotels in Nairobi County, Muteti and Muhoho (2019) concluded that continued and improved leadership strategic direction would further foster the performance of the hotels. Hassan, Mugambi and Waiganjo (2018), in their study titled "Effect of Training on the Performance of the Star Rated Hotels in Kenya", concluded that training contributed notably to hotel performance in Kenya. Ndiba and Mbugua (2018), in their study titled "The Effects of Customer Service Practices on Performance in the Hospitality Industry: A Case Study of Hotels in Nairobi County, Kenya", concluded that for hotels to perform better, they should improve existing marketing strategies and also implement marketing that focus on customer orientation. Wambua (2014), in her study on "Factors Influencing Sales Performance in the Hotel Industry: A case of Three-Star Hotels in Nakuru Municipality", indicated that policy and management, along with increased investments in quality of service as well as the hotel infrastructure, had markedly influenced sales performance of the three-star hotels.

The above studies present various factors that influence the performance of hotels in Kenya. This therefore puts across the need for a study to fill the existing gaps and clear the doubt on the influence of Electronic Personalization on hotel performance. It is on this background that the study sought to answer the question: Can Electronic Personalization be the solution to the performance of the Three to Five-Star Hotels in Kenya?

\section{Research Objectives}

To assess the influence of Electronic Personalization on Performance of Three to Five-Star Hotels in Kenya is the main purpose of this study. 


\section{Literature Review}

This section reviews studies and theoretical basis that compares with the study at hand so as to provide a backing on the study concepts and parameters.

\section{Theoretical Review}

Identify, Differentiate, Interact and Customize (IDIC) model, which was built by Peppers and Rogers (2004), pointed out that businesses should take four steps which are: Identification of customers, Differentiation of customers per need, Customization of messages to customers, and Interaction with customers. These four steps are implemented by companies in order to create, sustain, and retain long-term one-to-one customer influences. Customization and differentiation are influenced by customer evaluation while Interaction and Identification are customer interactions. The model helps in the implementation of electronic customer relationship management. It aids in acquiring and using customer information in identifying the customer at any electronic touch point so as to improve customer service. It also helps organizations by supporting the customer experiences, improve marketing activities within a company, and lastly improve company communication with the customers.

\section{Methodology}

The study adopted a descriptive research design and qualitative research approach was further utilized. The target population for the study was one hundred and twelve Three to Five-Star Hotels in Kenya. The descriptive design sought to find out electronic personalization influence on the performance of Three to Five-Star Hotels. It attempted to make specific predictions about performance of three to five-star hotels in Kenya. Descriptive research is a process of collecting data to answer questions concerning current status of the subjects in the study. It determines and reports the way things are with the subjects and it attempts to describe things such as behavior, attitude, values, and characteristics (Mugenda \& Mugenda, 2013). T-test and F- Statistic at 5\% level of significant was used to examine significance of coefficients of variables in the model. Explanatory power of electronic personalization on performance of Three to Five-Star Hotels for the total period of observation and adjusted coefficient of determination $\left(R^{2}\right)$ was performed. Also, Ordinary Least Square (OLS), simple regression analysis, and Pearson correlation test was performed on data set (Greene, 2012).

The Three to Five-Star Hotels were used because they form the majority share of Kenya's hotel industry. A survey was conducted on the target population. Simple regression model was estimated to draw inference from the data collected. SPSS was utilized for statistical analysis. Electronic 
personalization was measured using physical customer data capture at entry and exist, while Customer intimacy was achieved using Email \& Social media marketing, phone calls and Short message services.

$$
\mathrm{Y}_{\mathrm{i}}=\beta_{0}+\beta_{1} \mathrm{X}_{\mathrm{i}}+\varepsilon_{\mathrm{i}}
$$

Where subscript ' $i$ ' denotes the $i^{\text {th }}$ row in the data matrix

The Ordinary Least Square method of parameter estimation was implemented via SPSS version 23 (Greene, 2012).

$\beta_{1}$ represents the specific beta coefficient, $X_{i}$ represents electronic personalization, $\varepsilon_{\mathrm{i}}$ represents the error term in the model, $\mathrm{B}_{0}$ represents the constant while $Y_{i}$ represents hotel performance.

Electronic Personalization refers to the electronic marketing strategy that involves identifying customers and recognizing their needs so as to establish influences with them. Kamarudin, Aziz and Bakht (2011) concluded that hotel performance can be measured in terms of Occupancy Percentage Rate. Ilieva and Ivanov (2014) asserted that hotel performance can be measured in terms of online reviews and customer survey. Lee (2010) emphasized that Electronic Personalization can be measured by physical customer data capture (Data Mining) with the customers. Jutla, Bodorik and Dhaliwal (2002) concluded that Electronic Personalization can be measured by customer intimacy that involves various strategies such as the use of email \& social media marketing, phone calls, and short message services.

Two diagnostic tests were carried out on this - Multicollinearity test and normality test. The normality test was carried out to determine if the data for the study variables had a normal distribution, while the Multicollinearity test was carried out to determine if a perfect/exact relationship exist between the predictor variables.

\section{Findings and Discussions}

\section{Reliability Tests Results}

Reliability analysis for internal consistency of the measured items in measuring e-personalization gave a reliability Cronbach alpha value of 0.735 , with some items dropped. This results is above the 0.7 minimum acceptable range of the Cronbach's alpha, indicating a high level of internal consistency (Zikmund, 2013). The retained items were aggregation of leading to the study variable which in the foregoing sections we refer to as $\mathrm{X}$ (e-personalization). 


\section{Descriptive Analysis}

Table 1. e-personalization Descriptive Analysis

\begin{tabular}{llllll}
\hline & $\mathrm{N}$ & Mean & Std. Deviation & Skewness & \\
& Statistic & Statistic & Statistic & Statistic & Std. Error \\
e-personalization & 82 & 4.524 & .5654 & -1.832 & .266 \\
Performance & 82 & 4.0144 & .05583 & -.133 & .226 \\
Valid N (listwise) & 82 & & & & \\
\hline
\end{tabular}

From the findings presented in Table 1, the mean for electronic personalization was 4.524, which suggests that the use of electronic personalization in the Three to Five-Star Hotels stands at $4.52 \%$. Findings further revealed a standard deviation of 0.5654 which suggest that the variation of electronic personalization among the Three to Five-Star Hotels is not overly dispersed. Table 1 further presents the skewness of the electronic personalization as -1.832 . This suggests that the frequency distribution for electronic personalization does not significantly deviate away from the normal.

The findings presented in Table 1 further revealed a mean for hotel performance as 4.0144 with a standard deviation of 0.05583 . This suggests that the average performance of Three to Five-Star Hotels performance was $4.0 \%$. The findings also revealed a skewness of -1.33 for hotel performance frequency distribution, indicating that the distribution does not significantly deviate away from a normal distribution. Kothari (2004) argues that symmetric distributions (normally distributed) have a skewness of zero. This suggests that the frequency distribution for electronic personalization and hotel performance does not significantly deviate away from a normal distribution.

The study carried out diagnostic tests: normality test. The normality test was carried out to determine if the data for the study variables had a normal distribution. The results from the diagnostic tests would determine if the assumptions of simple regression model were satisfied.

\section{Test of Normality}

Table 2. Test of Normality

\begin{tabular}{lllllll}
\hline & \multicolumn{3}{l}{ Kolmogorov-Smirnov } & \multicolumn{4}{l}{ Shapiro-Wilk } \\
\cline { 2 - 7 } $\begin{array}{l}\text { Electronic } \\
\text { Statistic }\end{array}$ & Df & Sig. & Statistic & df & Sig. \\
\cline { 2 - 7 } $\begin{array}{l}\text { Personalization } \\
\text { Performance }\end{array}$ & .084 & 82 & .000 & .787 & 82 & .000 \\
\hline
\end{tabular}

a. Lilliefors Significance Correction 
Table 2 presents the results for the test of normality for the data collected. Kothari (2004) argues that a significance value of more than 0.05 for the Kolmogorov-Smirnov test signifies normality in a distribution. Thus, the study variables, Electronic Personalization, had a significance value of 0.00 while hotel performance had a significance value of 0.20 . This suggests that the two study variables were normally distributed. In this light, simple data regression model was utilized to analyze the primary data collected. This is based on the fact that the simple regression error term satisfied the normality assumption.

\section{Multi-Collinearity Test}

From the results portrayed in Table $3 \mathrm{a}$, there was no multi-collinearity between the independent variable (e-personalization) and the dependent variable (hotel performance) as the VIF values lies between 1 and 10 and that they (1.322) are all less than 4. Hence, there is very little or no multicollinearity presence in the study. This was supported by the Pearson correlation coefficient of .454. This exhibited positive results; hence the variable was selected for further regression analysis.

Table 3a. Multi-Collinearity Test

\begin{tabular}{lll}
\hline Variable & Tolerance & VIF \\
E-personalization & .756 & 1.322 \\
\hline
\end{tabular}

\section{Regression Results}

The study used simple regression analysis to determine the linear statistical relationship between the independent and dependent variable of the study. The null hypothesis of the study was tested using linear regression models. F- test was used to test the validity of the model, while $\mathrm{r}^{2}$ was meant to measure the model's goodness of fit. The regression coefficient was used to describe the results of regression analysis and outline the nature and intensity of the relationships between the variables under study.

Table 3b. Model Summary

\begin{tabular}{|c|c|c|c|c|}
\hline Model & $\mathrm{R}$ & R Square & $\begin{array}{l}\text { Adjusted } \\
\text { R Square }\end{array}$ & Std. Error of the Estimate \\
\hline 1 & $.605^{\mathrm{a}}$ & 0.366 & 0.357 & 0.41195 \\
\hline \multicolumn{5}{|c|}{ a. Predictors: (Constant), electronic Personalization } \\
\hline
\end{tabular}

Table $3 b$ presents the simple regression results on the influence of Electronic Personalization on performance of Three to Five-Star Hotels in Kenya. The regression model of Electronic Personalization $\left(\mathrm{X}_{1)}\right.$ and hotel performance $(\mathrm{Y})$ was significant $(\mathrm{F}(1,78)=44.939$, P-value $<0.001)$. Hence, Electronic Personalization is a valid predictor in the model. The Coefficient of determination $\mathrm{R}^{2}$ of 0.366 showed that $36.6 \%$ of hotel performance can be 
explained by the dimension of Electronic Personalization in electronic customer relationship management. The adjusted $\mathrm{R}^{2}(0.357)$ indicates that $35.7 \%$ of the remaining (non-significant predictors) can be explained by other factors not included in the model.

The Pearson's Correlation Coefficient for Electronic Personalization and hotel performance $(\mathrm{r}=0.605$, $\mathrm{p}$-value $<0.001)$ was significant at 0.05 level of significance. The Regression Analysis results showed that Electronic Personalization had a strong influence on hotel performance in Three to FiveStar Hotels in Kenya. For every unit increase in the extent of Electronic Personalization in e-CRM, there was a corresponding increase in hotel performance index by 0.603 . The dimension of Electronic Personalization in e-CRM positively influences the performance of Three to Five-Star Hotels in Kenya.

From Table 4, the findings revealed that the regression model of $\mathrm{X}_{1}$ and $\mathrm{Y}$ was significant $(\mathrm{F}(1,78)=44.939$, $\mathrm{P}$-value $<0.001)$, concluding that Electronic Personalization is a valid predictor in the model. The results on Table 3 further reveal a significance value of .000 which is less than .05. This suggests that Electronic Personalization has a significant influence on performance of Three to Five-Star Hotels in Kenya (p-value < 0.001).

Table 4. ANOVA

\begin{tabular}{lllllll}
\hline Model & & Sum of Squares & Df & Mean Square & F & Sig. \\
1 & Regression & 7.626 & 1 & 7.626 & 44.939 & $.000^{\mathrm{a}}$ \\
& Residual & 13.237 & 78 & .170 & & \\
& Total & 20.863 & 79 & & & \\
\multicolumn{7}{l}{ a. Predictors: (Constant), electronic Personalization } \\
\hline
\end{tabular}

Table 5. Coefficients

\begin{tabular}{cccccc}
\hline & $\begin{array}{c}\text { Unstandardized } \\
\text { Coefficients } \\
\text { B }\end{array}$ & Std. Error & $\begin{array}{c}\text { Standardized } \\
\text { Coefficients } \\
\text { Beta }\end{array}$ & T & Sig. \\
(Constant) & 4.025 & 0.046 & & 87.362 & 0 \\
Electronic & 0.603 & 0.09 & 0.605 & 6.704 & 0 \\
Personalization & & & & & \\
\hline
\end{tabular}

Table 5 revealed that there was positive influence between Electronic Personalization and performance of Three to Five-Star Hotels in Kenya.

The study hypothesized Ho $\mathrm{H}_{1}$ : Electronic Personalization does not influence performance of the Three to Five-Star Hotels in Kenya. The results of the survey revealed that there was positive influence between Electronic Personalization and performance of Three to Five-Star Hotels in Kenya ( $\beta 1=$ $0.603, \mathrm{t}=6.704$, $\mathrm{p}$-value $<0.001$ ). 
The null hypothesis (Ho): Electronic Personalization does not influence performance of the Three to Five-Star Hotels in Kenya. Ho1: $\beta 1=0$ is therefore rejected $(\beta 1=0.603, t=6.704, p$-value $<0.05)$ it is concluded that Electronic Personalization $\left(\mathrm{X}_{1}\right)$ significantly influences hotel performance $(\mathrm{Y})$.

\section{Empirical Review}

A study conducted by Sekhon (2015) asserted that Electronic Personalization improves the likelihood of repeat visits of customers, hence improved business performance. This indicates that Electronic Personalization is necessary because it enhances revenues for the company as well as increases the user satisfaction. Electronic Personalization of the customer experience is one of best opportunities for attracting, retaining, and building loyalty with your customers, which ultimately leads to a competitive advantage. Another study by Arora and Dreze (2008) observed that Electronic Personalization is positively correlated to sustainable advantages and higher industry profits. In addition, Salonen and Karjaluoto (2016) concluded that satisfaction and loyalty are key concepts in web Electronic Personalization because they are considered essential drivers of business performance. Ho and Bodoff (2014) stated that there is a positive correlation of Electronic Personalization in increasing business performance in terms of increasing both advertising and sales revenues.

Lixandroiu and Maican (2015) asserted in their study that Electronic Personalization is possible in electronic commerce with the use of online marketing and digital service innovation. This way a highly relevant, engaging and enhanced user customer is provided, causing a significant increase in the conversion rates and revenue for companies. Electronic Personalization and company performance is also supported by Srinivasan, Anderson and Ponnavolu (2002), who concluded that Electronic Personalization allows companies in electronic commerce sphere to grow and improve influences with customers by creating clients' profiles based on what they like and how they behave. Providing excess information and helping customers in making smart decisions increases their loyalty level and their business performance.

Furthermore, Ansari and Mela (2003) found out that Electronic Personalization has also shown a steady increase in customers' satisfaction level. Electronic Personalization relies on assigning the right marketing effort to the right customer. Finally, Malthouse and Elsner (2006) had compelling evidence study conclusion that the hotel saw a significant increase in revenue and was successful in retaining its customers in the use electronic personalization. Furthermore, they added that the advantages of Electronic Personalization are greater customer satisfaction and higher profits. 


\section{Discussion}

From the findings of this study, Electronic Personalization has a significant influence on hotel performance in Three to Five-Star Hotels in Kenya. This result on the effect of Electronic Personalization on hotel performance have been supported by JungKook (2107), who reported that Electronic Personalization meets customer's needs more effectively and efficiently. This thus results in faster customer interactions which increases customer satisfaction. This improves the likelihood of repeat visits, hence improved business performance. In addition, Sekhon (2015) found that effective Electronic Personalization is mandatory to enhance the revenue for the company as well as to increase the user satisfaction.

These study findings are also supported by Oracle Corporation (2011), who found that Electronic Personalization of customer experience is one of best opportunities for attracting, retaining, and building loyalty with your customers, which ultimately leads to a competitive advantage. The study findings also dovetail with the results of Arora and Dreze (2008) who found that Electronic Personalization is positively correlated to sustainable advantages and higher industry profits. Finally, Electronic Personalization allows companies to reach people who want to know about their products and services instantly (Bonett, 2001).

\section{Conclusion}

Study findings reveal that Electronic Personalization influence performance of Three to Five-Star Hotels. Thus, if a hotel wants to perform at a significantly higher level than its competitors, it should pursue electronic personalization by ensuring that they regularly use their social media platforms in communication to their customers. They should also use their social media platforms to constantly personalize their communication with their customers. The hotels should identify customer's information, identify and be aware of purchase lists history, as well as the possibility to track and log each customer's navigation actions. This assists the hotels in being in a position to suggest hotel products or services which may be of interest to customers. In return it increases both consumer's loyalty or satisfaction and benefits in terms of profits. Finally, Electronic Personalization enables hotel to predict the customers' needs, hence making the hotel meet these needs and, at the end, this leads to an increase in hotel performance.

\section{References:}

1. Alatalo, T., \& Siponen, M. (2001). Addressing the epersonalizationparadox in the development of electronic commerce systems. In post-proceedings of the E-business research forum $(e B R F)$.Tampere, Finland. 
2. Arora, N., \& Dreze, X. (2008). Putting one-to-one marketing to work: E-personalization, customization and choice. Springer Science. 19(2), 305-321.

3. Bonett, M. (2001, July Tuesday). "Electronic personalization of web services: opportunities and challenges", Ariadna. E-personalization of web services: opportunities and challenges, 28. United Kindom. Retrieved, July $4^{\text {th }}, 2021$, from http://www.ariadne.ac.uk/issue28/epersonalization/intro.html.

4. Greene, W. H. (2012). Econometric Analysis. England: Pearson Education Limited.

5. Hassan, I. B., Mugambi, F., \& Waiganjo, E. (2018). Effect of Training on the Performance of the Star Rated Hotels in Kenya. International Journal of Business and Commerce, 6(4), 53-64.

6. Ilieva, D., \& Ivanov, S. (2014). Analysis of online hotel ratings: the case of Bansko, Bulgaria. Yearbook of International University College, 9(1), 1-10.

7. Ishmael, N. (2015). A Framework for Post Implementation Evaluation of e-CRM in Telecommunication Sector: The case of Orange Kenya. International Academic Journal of Information Systems and Technology, 1(5), 18-39.

8. Jutla, D., Bodorik, P. \& Dhaliwal, J. (2002). Supporting the e-business readiness of small and medium-sized enterprises: approaches and metrics. Internet Research, 12(2), 139 -164.

9. JungKook, L. (2107). e-personalizationand online, epersonalizationand online privacy features: the case with travel websites. Journal of Management and Marketing Research.

10. Kamarudin, A. A., Aziz, S. Y. \& Bakht (2011). Customer segmentation approaches and hotel occupancy performance, a case study of 4 and 5 star hotels in Klang Valley". Journal of Tourism, Hospitality \& Culinary Arts, 3(3), 109-125.

11. Lee, K., Kim, H., Kim, H., \& Lee, D. (2010). The Determinants of Factors in FIT Guests' Perception of Hotel Environment. Journal of Hospitality and Tourism Management, 17, 169-174.

12. Lixandroiu, R., \& Maican, C. (2015). Electronic personalizationin Ecommerce using profiles similarity. Economic Sciences, 8(57), 10-30.

13. Macharia, J., \& Thuo, C. (2011). Serving Global Customers: Adoption Of (E-CRM) By Small And Medium Enterprises (SMES) In Kenya. International Journal of Current Research, 33(6), 270-277.

14. Mang'unyi, E. E., Khabala, O. T., \& Govender, K. K. (2017). The influence between e-CRM and customer loyalty: a Kenyan case study. Banks and Bank Systems, 12(2), 106-115. 
15. Mittal , B., \& Lassar, W. M. (1996). "The role of e-personalization in service encounters". Journal of Retailing, 72(1), 95-109.

16. Mugenda, A. \& Mugenda, O. (2013). Research methods: Quantitative and qualitative approaches. Nairobi: ACTS Press.

17. Muteti, P. N., \& Muhoho, J. (2019). Leadership practices and performance of five star hotels in Nairobi county, Kenya. The Strategic Journal of Business \& Change Management, 6(3), 634-720.

18. Ndiba, C. W. \& Mbugua, D. (2018). Effect of customer service practices on performance in the hospitality industry: a case study of hotels in Nairobi county, Kenya. International Journal of Social Sciences and Information Technology, 4(5), 142-151.

19. Oracle Corporation (March 2011). How to Win Online: Advanced Epersonalizationin E-Commerce. Oracle Parkway Redwood Shores: Oracle.

20. Onyeocha, A. O. \& Chinonso, I. (2015). The impact of e-marketing and services: to achieving effective customer's service in the hospitality industry in Nigeria. Merit Research Journal of Business and Management, 3(5), 056-065.

21. Peppers, D. \& Rogers, M. (2004). Managing Customer Relationships, A startegic Framework. New Jersey: John Wiley \& Sons, Inc.

22. Sekhon, A. (2015). E-Commerce E-personalization by Internet Of Things. Unpublished Thesis at University of Ottawa, Canada.

23. Shahram, G. \& Farhad, S. N. (2013). Impact of eCRM on creating competitive advantage in hotels of Sarein. Arabian Journal of Business and Management Review, 3(4), 77-85.

24. Wambua, D. K. (2014). Factors influencing sales performance in the hotel industry: a case of three star hotels in Nakuru municipality. Unpublished Thesis at Egerton University, Kenya.

25. Zikmund, W. G. (2013). Business Research Methods. Natorp Boulevard: Cengage Learning. 